\title{
PENERAPAN MODEL PEMBELAJARAN MAKE A MATCH UNTUK MENINGKATKAN MOTIVASI BELAJAR DAN PRESTASI BELAJAR MATEMATIKA SISWA
}

\author{
Ludmila Sesfaot $^{1}$, Yusak I.Bien ${ }^{2}$, Alfonsa M.Abi ${ }^{3}$ \\ ${ }^{1,2,3}$ Program Studi Pendidikan Matematika, STKIP Soe, Indonesia \\ milasesfaot464@gmail.com
}

\begin{abstract}
This study aims to improve student motivation and learning achievement in mathematics through the make a match model. This type of research is Class Action Research. The research subjects were class VIII students of 1 Soe Christian Middle School with 24 people. Data collection techniques used were tests, observations and questionnaires, the data analysis techniques in this study were quantitative and qualitative data analysis. The results of this study indicate that using the make a match learning model can increase learning motivation and mathematics learning achievement of class VIII students of 1 Christian Middle School Soe. The average percentage of learning motivation in the first cycle is $71 \%$ and the second cycle is $90 \%$. While the average percentage of learning motivation questionnaires in cycles I is $76 \%$ and cycles II is $82 \%$. Students' mathematics learning achievements also increased significantly because the average value in the first cycle was 76,46 with a percentage of completeness of $71 \%$ and in the second cycle with an average of 86,88 or students who completed at $92 \%$. It can be concluded that there is an increase in student learning motivation and student achievement in cycles I and II the aplication make a match learning model.
\end{abstract}

Keywords: make a match, motivation to learn, mathematics learning achievement.

\begin{abstract}
Abstrak
Penelitian ini bertujuan untuk meningkatkan motivasi belajar dan prestasi belajar matematika siswa melalui model pembelajaran make a match. Jenis penelitian ini adalah Penelitian Tindakan Kelas . Subjek penelitian adalah siswa kelas VIII SMP Kristen 1 Soe sebanyak 24 orang. Teknik pengumpulan data yang digunakan adalah tes, observasi dan angket, teknik analisis data menggunakan analisis data kuantitatif dan kualitatif. Hasil penelitian menunjukkan bahwa dengan menggunakan model pembelajaran make a match dapat meningkatkan motivasi belajar dan prestasi belajar matematika siswa kelas VIII SMP Kristen 1 Soe. Meningkatnya motivasi belajar dilihat dari rata-rata persentase observasi motivasi belajar pada siklus I adalah $71 \%$ dan siklus II adalah $90 \%$, sedangkan rata-rata persentase angket motivasi belajar pada siklus I adalah $76 \%$ dan siklus II adalah $82 \%$. Prestasi belajar matematika siswa juga meningkat secara signifikan dilihat dari nilai rata-rata pada siklus I adalah 76,46 dengan persentase ketuntasannya $71 \%$ dan pada siklus II dengan rata-rata 86,88 atau siswa yang tuntas sebesar 92\%. Dapat disimpulkan bahwa ada peningkatan motivasi belajar siswa dan prestasi belajar matematika siswa dengan penerapan model pembelajaran make a match.
\end{abstract}

Kata kunci: make a match, motivasi belajar, prestasi belajar matematika

\section{PENDAHULUAN}

Pendidikan memegang peran penting dalam mencerdaskan kehidupan bangsa karena pendidikan merupakan penentu kemajuan suatu bangsa, maju mundurnya suatu bangsa tergantung pada pengetahuan dan keterampilan warga negaranya, oleh karena itu mutu pendidikan perlu ditingkatkan terus menerus. Motivasi dan prestasi belajar merupakan bagian terpenting yang tidak dipisahkan dari berhasilnya suatu proses pendidikan untuk mencapai mutu pendidikan yang diinginkan. Motivasi belajar mempunyai peranan yang sangat penting untuk mencapai keberhasilan 
belajar (Nurmalia, Alzaber dan Helina, 2019). Belajar merupakan kegiatan fundamental dalam proses pendidikan di sekolah.

Matematika merupakan salah satu mata pelajaran yang menunjang kegiatan pendidikan. Matematika merupakan ilmu universal yang mendasari perkembangan teknologi, mempunyai peran penting dalam berbagai disiplin ilmu dan memajukan daya pikir manusia (Depdiknas, 2006). Matematika juga merupakan kegiatan pembelajaran yang diselenggarakan untuk memfasilitasi, meningkatkan intensitas dan kualitas belajar pada diri siswa (Winataputra dkk, 2007). Pelajaran matematika diberikan kepada siswa berjenjang mulai dari sekolah dasar sampai perguruan tinggi. Matematika sering dianggap sebagai pelajaran yang membosankan, pelajaran yang paling tidak disenangi oleh siswa karena melibatkan banyak rumus sehingga mengakibatkan prestasi belajar matematika siswa rendah. Prestasi belajar matematika siswa SMP di Indonesia masih jauh tertinggal dengan negara lain.

Hasil PISA (Programme for International Student Assessment) 2015 menunjukkan bahwa Indonesia berada pada peringkat 69 dari 76 negara, sedangkan hasil TIMSS (Trends in International Mathematics and Science Study) 2015 menunjukkan bahwa Indonesia berada pada peringkat 45 dari 50 negara (Rahmawati \& Marsigit, 2017). Ini berarti prestasi belajar matematika siswa di Indonesia masih rendah. Rendahnya prestasi belajar matematika juga dialami oleh siswa kelas VIII di SMP Kristen 1 Soe yang mana tampak dari nilai rata-rata UAS matematika kelas VIII semester ganjil tahun 2018/2019 sebanyak 2 kelas adalah 64,25 dengan Kriteria Ketuntasan Minimal (KKM) yang ditentukan oleh sekolah adalah 68. Banyaknya siswa yang tuntas adalah 24 orang dari 63 atau hanya $38,09 \%$ jauh dari KKM yang ditetapkan.

Selain prestasi belajar matematika siswa di sekolah tersebut rendah, motivasi siswa dalam belajar pun masih rendah. Hal ini diketahui melalui observasi siswa saat pembelajaran bahwa siswa kurang berminat dengan matematika, kurang perhatian, suka bermain, bosan, suka ijin keluar masuk kelas saat pelajaran berlangsung. Apabila siswa termotivasi untuk belajar matematika, maka prestasi belajar siswa juga akan sangat memuaskan (Sutarniyati, 2016). Motivasi belajar adalah suatu daya, dorongan atau kekuatan baik yang datang dari diri sendiri maupun dari luar yang mendorong siswa untuk belajar (Sumartono \& Normalina, 2015). Indikator motivasi belajar siswa dapat diklasifikasikan sebagai berikut: a) adanya dorongan dan kebutuhan belajar, b) menunjukan perhatian dan minat terhadap tugas yang diberikan, c) tekun menghadapi tugas, d) ulet menghadapi kesulitan, e) adanya hasrat dan keinginan berhasil (Lestari \& Yudhanegara, 2017). Prestasi belajar matematika adalah tingkat keberhasilan yang telah dicapai siswa dalam mengikuti proses belajar mengajar yang ditunjukkan dengan angka atau nilai tes (Rahmawati \& Marsigit, 2017).

Salah satu penyebab rendahnya motivasi dan prestasi belajar matematika siswa adalah penggunaan model pembelajaran yang kurang tepat. Oleh karena itu, salah satu model pembelajaran yang tepat untuk meningkatkan motivasi belajar dan prestasi belajar matematika siswa adalah model pembelajaran make a match. Melalui model kooperatif tipe make a match hasil belajar matematika 
siswa meningkat (Soleha, 2016; Rahmayanti \& Koeswanti, 2017; Sukaisih, 2019). Hasil penelitian Saparwadi (2015) menunjukkan bahwa terdapat pengaruh cooperative learning tipe make a match terhadap motivasi dan hasil belajar matematika siswa. Selain itu, Nurmalia, Alzaber \& Helina (2019) dalam penelitiannya diperoleh bahwa penerapan model pembelajaran kooperatif tipe make a match dapat memperbaiki proses pembelajaran dan meningkatkan motivasi belajar matematika siswa.

Menurut Huda, model pembelajaran make a match adalah salah satu pendekatan konseptual yang mengajarkan siswa memahami konsep-konsep secara aktif, kreatif, efektif, interaktif dan menyenangkan bagi siswa sehingga konsep mudah dipahami dan bertahan lama dalam struktur kognitif siswa (Rahmayanti \& Koeswanti, 2017). Model pembelajaran make a match adalah kegiatan siswa untuk mencari pasangan kartu yang merupakan jawaban soal sebelum batas waktunya, siswa yang dapat mencocokkan kartunya akan diberi poin dan yang tidak berhasil mencocokkan kartunya akan diberi hukuman sesuai dengan yang telah disepakati bersama (Purwanto \& Harini, 2016).

Adapun langkah-langkah model pembelajaran make a match menurut Lestari \& Yudhanegara, (2017) adalah (a) guru menyiapkan beberapa kartu yang berisi beberapa konsep atau topik yang cocok untuk sesi review,satu bagian lainnya kartu jawaban, (b) setiap siswa mendapatkan sebuah kartu yang bertuliskan soal/jawaban, (c) tiap siswa memikirkan jawaban/soal dari kartu yang dipegang, (d) setiap siswa mencari pasangan kartu yang cocok dengan kartunya. (e) setiap siswa yang dapat mencocokkan kartunya sebelum batas waktu diberi poin, (f) setelah satu babak, kartu dikocok lagi agar tiap siswa mendapat kartu yang berbeda dari sebelumnya, demikian seterusnya. (g) kesimpulan atau penutup. Tujuan penelitian ini adalah untuk meningkatkan motivasi belajar dan prestasi belajar matematika siswa melalui penerapan model pembelajaran make a match.

\section{METODE}

Jenis penelitian yang digunakan adalah penelitian tindakan kelas (PTK). PTK merupakan jenis penelitian yang memaparkan baik proses maupun hasil dalam melakukan tindakan di kelasnya untuk meningkatkan kualitas pembelajaran (Arikunto dkk, 2006). Penelitian ini menggunakan model penelitian tindakan dari Kemmis dan Taggart (Maridjo, 2010) yaitu berbentuk spiral dari siklus yang satu ke siklus yang berikutnya. Model PTK ini didesain dalam empat komponen pada setiap siklus yakni, (1) perencanaan (planning), (2) tindakan (acting), (3) pengamatan (observing) dan (4) refleksi (reflecting). Model PTK ini digambarkan pada Gambar 1.

PTK ini dilakukan dalam dua siklus, setiap siklus terdiri dari empat tahapan yaitu perencanaan, pelaksanaan, pengamatan dan refleksi. Kegiatan yang dilakukan pada tahap perencanaan antara lain membuat Rencana Pelaksanaan Pembelajaran (RPP) dan skenario pembelajaran dengan menggunakan model pembelajaran make a match, menyusun soal tes, menyiapkan angket (kuesioner) untuk mengukur motivasi belajar siswa dalam pembelajaran dengan model make a match, mempersiapkan lembar observasi untuk mengevaluasi proses pembelajaran yang berlangsung melalui dengan model kooperatif tipe make a match. Pada tahap pelaksanaan kegiatan yang dilakukan yaitu melaksanakan 
pembelajaran sesuai perencanaan, sedangkan tahap pengamatan dilakukan selama proses pembelajaran berlangsung. Pada tahap refleksi kegiatan yang dilakukan yaitu mengevaluasi setiap tindakan yang telah dilakukan; pada tahapan refleksi ini jika terdapat kekurangan maka akan diperbaiki agar pelaksanaan pada siklus selanjutnya dapat berjalan sesuai dengan yang diharapkan. PTK ini dilaksanakan dalam dua siklus karena berdasarkah hasil refleksi pada siklus kedua diketahui bahwa motivasi dan prestasi belajar siswa sudah tuntas sesuai dengan yang diharapkan.

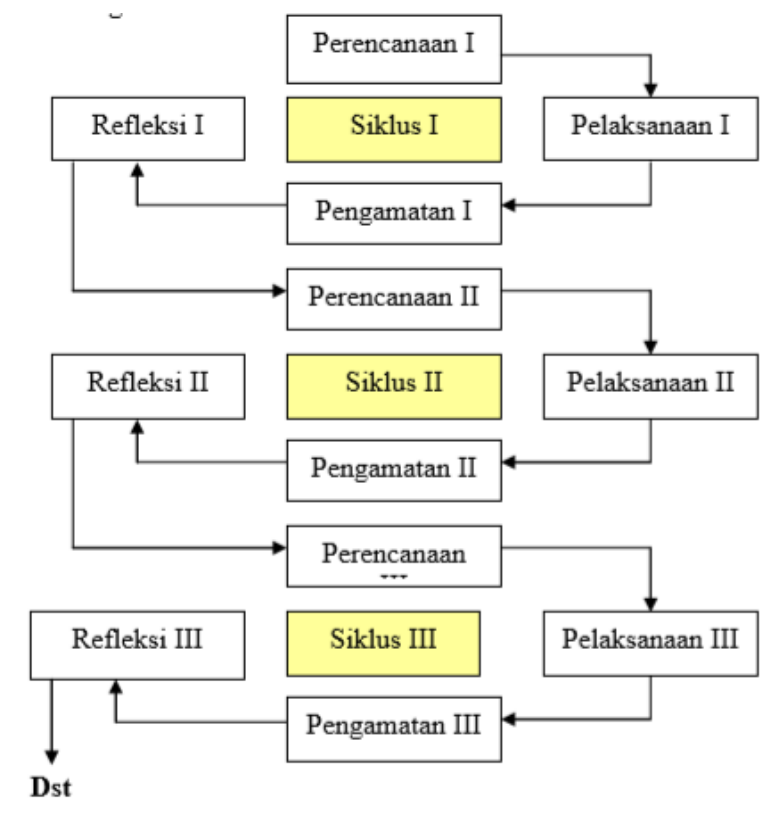

Gambar 1. Model PTK Kemmis dan McTaggart

Teknik pengumpulan data yang digunakan dalam penelitian ini adalah tes, observasi dan angket. Teknik analisis data dalam penelitian ini menggunakan analisis data kuantitatif dan kualitatif. Data yang diperoleh dari hasil tes dianalisis secara kuantitatif untuk mengetahui peningkatan prestasi belajar matematika siswa, sedangkan lembar observasi dan kuesioner dianalisis secara deskriptif untuk mengetahui motivasi belajar siswa. Penelitian ini dikatakan berhasil apabila terdapat peningkatan prestasi belajar dengan kriteria: (1) ketuntasan individu apabila mencapai nilai minimal 68 dan (2) ketuntasan klasikal apabila terdapat minimal 75\% siswa telah mencapai nilai minimal 68.

\section{HASIL}

Penelitian ini dilakukan pada siswa kelas VIII SMP Kristen 1 Soe, tahun pelajaran 2018/2019 selama empat minggu pada bulan Mei 2019 dengan subjek penelitian terdiri dari 24 siswa. Berdasarkan hasil penelitian dan analisis data yang telah dilakukan, maka pembahasan pada penelitian ini didasarkan pada lembar observasi guru, angket motivasi siswa serta hasil tes ketuntasan belajar siswa pada setiap siklus. Kegiatan pembelajaran pada siklus I dan II dilaksanakan dalam 
empat kali pertemuan dimana setiap siklus dilakukan dalam dua kali pertemuan. Persentase peningkatan motivasi belajar siswa pada setiap siklus ditunjukkan oleh Gambar 2.

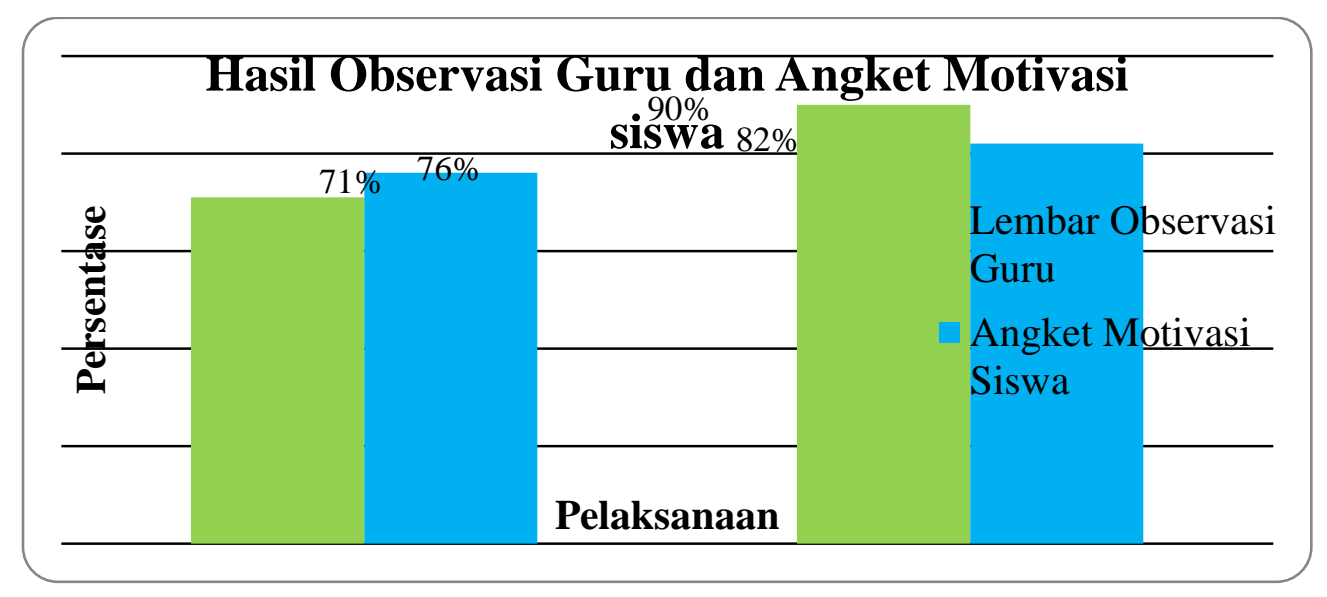

Gambar 2. Hasil observasi guru dan angket motivasi siswa

Gambar 2 menunjukkan bahwa motivasi belajar matematika siswa kelas VIII SMP Kristen 1 Soe sangat baik dikarenakan hasil observasi yang dilakukan oleh dua orang guru diperoleh rata-rata motivasi belajar pada siklus I adalah 71\% dan siklus II adalah 90\% sedangkan berdasarkan 20 item pernyataan yang diisi oleh seluruh siswa maka persentase angket motivasi belajar siswa pada siklus I adalah $76 \%$ dan siklus II adalah $82 \%$. Peningkatan motivasi belajar siswa terjadi sejak siklus I sampai dengan siklus II pada setiap indikatornya. Oleh karena itu, dapat disimpulkan bahwa penerapan model pembelajaran make a match dapat meningkatkan motivasi belajar matematika siswa kelas VIII SMP Kristen 1 Soe. Hal ini sesuai dengan penelitian (Sutarniyati, 2016) bahwa penerapan model pembelajaran make a match dapat meningkatkan motivasi belajar siswa. Penerapan model pembelajaran make a match meningkatkan aktivitas belajar siswa dan melatih keberanian dan kedisiplinan siswa dalam menghargai waktu selama mengikuti kegiatan pembelajaran. Hal inilah yang memotivasi siswa untuk semakin giat belajar matematika. Selain motivasi belajar meningkat, prestasi belajar siswa juga meningkat dilihat dari nilai tes siswa pada siklus I dan II yang ditunjukkan pada Gambar 3.

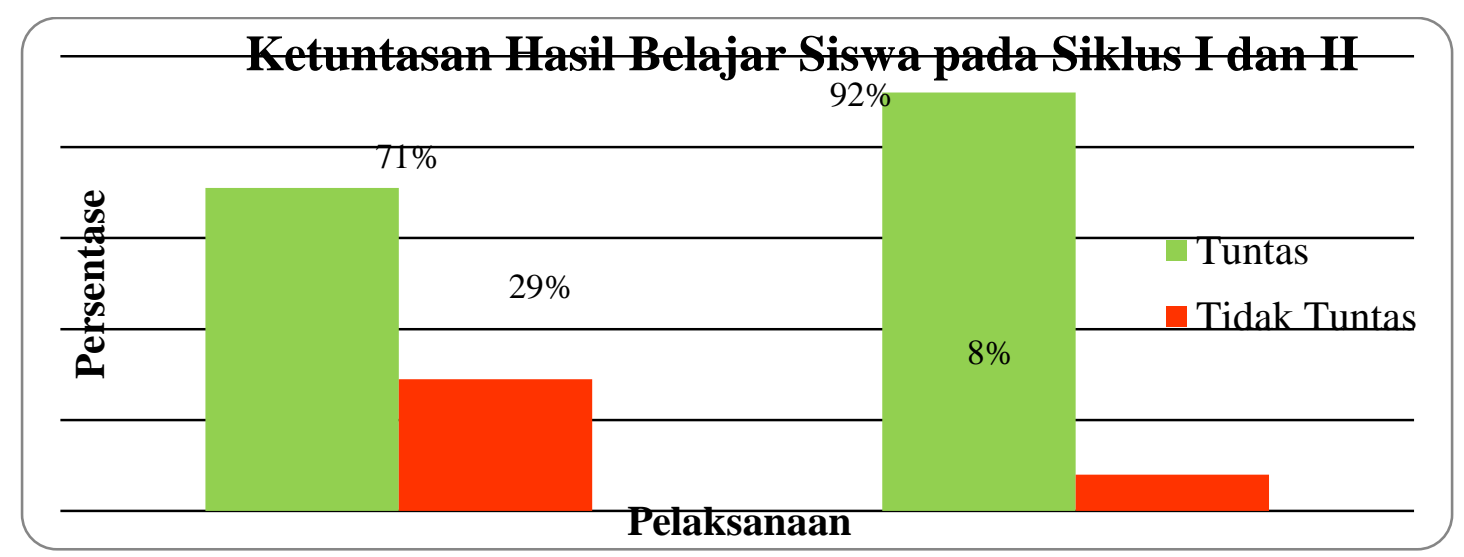

Gambar 3. Ketuntasan hasil belajar siswa pada siklus I dan II 
Gambar 3 menunjukkan bahwa siswa yang mencapai ketuntasan belajar pada siklus I adalah 17 orang dengan persentase $71 \%$ dan yang tidak tuntas adalah 7 orang dengan persentase $29 \%$ sedangkan pada siklus II yang tuntas adalah 22 orang dengan persentase $92 \%$ dan yang tidak tuntas adalah 2 orang dengan persentase $8 \%$. Rata-rata ketuntasan belajar siswa pada siklus I adalah 76,46 dan mengalami peningkatan pada siklus II sebesar $21 \%$ dengan nilai rata-rata 86,88 .

Hasil penelitian menunjukkan bahwa penerapan model pembelajaran make a match dapat meningkatkan prestasi belajar matematika siswa kelas VIII pada SMP Kristen 1 Soe. Hal ini sesuai dengan penelitian Rahmayanti \& Koeswanti (2017) bahwa penerapan model pembelajaran make a match dapat meningkatkan prestasi belajar matematika siswa. Model pembelajaran make a match dapat melatih siswa untuk berpikir lebih kritis dalam mencocokan setiap soal dan jawaban dengan tepat sehingga meningkatkan pemahaman siswa terhadap materi yang dipelajari.

\section{KESIMPULAN}

Berdasarkan hasil dan pembahasan dapat disimpulkan bahwa penerapan model pembelajaran make a match dapat meningkatkan motivasi belajar siswa dan juga dapat meningkatkan prestasi belajar matematika siswa kelas VIII SMP Kristen 1 Soe. Rata-rata persentase motivasi belajar meningkat dilihat dari hasil observasi oleh dua orang guru pada siklus I adalah $71 \%$ dan siklus II adalah 90\% sedangkan rata-rata persentase angket motivasi belajar pada siklus I adalah $76 \%$ dan siklus II adalah $82 \%$. Prestasi belajar matematika siswa juga meningkat secara signifikan dilihat dari nilai rata-rata pada siklus I adalah 76,46 dengan persentase ketuntasannya $71 \%$ dan pada siklus II dengan rata-rata 86,88 atau siswa yang tuntas sebesar 92\%. Dapat disimpulkan bahwa ada peningkatan motivasi belajar siswa dan prestasi belajar matematika siswa pada siklus I dan II dengan penerapan model pembelajaran make a match.

Berdasarkan hasil penelitian, disarankan agar dalam penerapan model pembelajaran make a match, khusus saat siswa mencari pasangan kartu yang cocok dengan kartunya, guru lebih memperhatikan agar suasana kelas tetap kondusif dan tertib.

\section{DAFTAR PUSTAKA}

Arikunto, S., dkk. (2006). Penelitian Tindakan Kelas. Jakarta: Bumi Aksara.

Depdiknas. (2006). Peraturan Menteri Pendidikan Nasional Nomor 22 Tahun 2006 tentang Standar

Isi. Jakarta: Direktorat Jenderal Manajemen Pendidikan Dasar dan Menengah. https://akhmadsudrajat.files.wordpress.com/2009/04/permendiknas-no-22-tahun-2006.pdf

Lestari, K., E., \& Yudhanegara, M.R . (2017). Penelitian Pendidikan Matematika. Refika Aditama. Maridjo. (2010). Rambu-rambu Penelitian Tindakan Kelas. Pontianak: Universitas Tanjungpur.

Nurmalia, Alzaber. \& Helina,S. (2019). Penerapan Model Pembelajaran Kooperatif Tipe Make a Match Untuk Meningkatkan Motivasi Belajar Matematika Siswa Kelas XI MIPA 1 SMA Negeri 1 Sentajo Raya Kabupaten Kuantan Singingi. Jurnal Aksiomatik, 7(1), 70-78. https://journal.uir.ac.id/index.php/AKS/article/view/2307/1689 
Purwanto, S. T., \& Harini, E. (2016). Peningkatan Minat dan Hasil Belajar Matematika melalui Pembelajaran Tipe Make a Match. UNION: Jurnal Pendidikan Matematika, 4(1), 109-116. https://doi.org/10.30738/.v4i1.415

Rahmawati, F. D \& Marsigit. (2017). Pengembangan Bahan Ajar Berbasis Etnomatematika Untuk Meningkatkan Prestasi dan Motivasi Belajar Siswa SMP. Jurnal Pendidikan Matematika, 6(6), 69-76.

Rahmayanti, I. D. S., \& Koeswanti, H. D. (2017). Penerapan Model Make a Match Untuk Meningkatkan Hasil Belajar Matematika Materi Siswa Kelas IV SD Negeri Diwak. UNION: Jurnal Ilmiah Pendidikan Matematika, 5(3), 209-218. https://doi.org/10.30738/.v5i3.1060

Saparwadi, L. (2016). Pengaruh Cooperative Learning Make a Match Terhadap Motivasi dan Hasil Belajar Matematika. Jurnal Pendidikan Matematika, 9(2), 148-160. http://jurnalbeta.ac.id Soleha. (2016). Penerapan Model Pembelajaran Kooperatif Tipe Make a Match Untuk Meningkatkan Hasil Belajar Matematika Siswa Kelas IV SD Negeri 2 Gayau Sakti Tahun Pelajaran 2014/2015. Jurnal Aksioma, $\quad$ 5(1), 68-74. http://ojs.fkip.ummetro.ac.id/index.php/matematika/article/view/467

Sukaisih, E. (2019). Meningkatkan Hasil Belajar Matematika Melalui Model Pembelajaran Kooperatif Tipe Make a Match Pada Materi Aritmetika Sosial. EDU-MAT: Jurnal Pendidikan Matematika, 7(1), 84-90. https://doi.org/10.20527/edumat.v7i1.6824

Sumartono, S., \& Normalina, N. (2015). Motivasi dan Hasil Belajar Siswa dalam Pembelajaran Matematika dengan Menggunakan Model Pembelajaran Kooperatif Tipe Scramble di SMP. EDU-MAT: Jurnal Pendidikan Matematika, 3(1), 84-91. https://doi.org/10.20527/edumat.v3i1.638

Sutarniyati, P. (2016). Peningkatan Motivasi Belajar Siswa Menggunakan Model Make a Match pada Pelajaran IPA Kelas V. Jurnal Pendidikan Matematika Dan Sains, 4(1), 43-49. http://journal.student.uny.ac.id/ojs/index.php/pgsd/article/view/5117

Winataputra U. S., dkk. (2007). Teori Belajar dan Pembelajaran. Jakarta: Universitas Terbuka. 